\title{
THE EXHAUSTION OF WATER RESOURCES IN THE KUYAVIAN-POMERANIAN VOIVODSHIP IN DROUGHT CONDITIONS IN 2015
}

\author{
Adam Solarczyk, Katarzyna Kubiak-Wójcicka \\ Nicolaus Copernicus University, Poland \\ adamsol@umk.pl
}

\begin{abstract}
The aim of the paper is to present the spatial diversity of water resources in the Kuyavian-Pomeranian Voivodship during the drought in 2015. The region's area is characterized by the lowest average annual precipitation in Poland, the lowest water resources and high water demand associated with intensive plant production. Hydrological research was carried out in September 2015 in 145 measurement points on various rivers. Despite the low precipitation recorded in August 2015 at the majority of meteorological stations, the volume of the specific discharge from the KuyavianPomeranian region was characterized by high variability. The largest specific discharges were recorded for rivers located in the northern part of the region whose sources are located in the Pomeranian Lake District, i.e. Brda and Wda (over $2 \mathrm{dm}^{3} \mathrm{~s}^{-1} \mathrm{~km}^{-2}$ ) and the Masurian Lake District (Drwęca over $1 \mathrm{dm}^{3} \mathrm{~s}^{-1} \mathrm{~km}^{-2}$ ). The smallest specific discharges (less than $0.5 \mathrm{dm}^{3} \mathrm{~s}^{-1} \mathrm{~km}^{-2}$ ) were recorded in the catchments located in the Kuyavian region (Tążyna, Zgłowiączka and Noteć) in the southern part of the Kuyavian-Pomeranian Voivodship and from the Osa River catchment. These areas are intensively used for agricultural purposes. The use of surface water resources as a potential source of irrigation water for crops can only be taken into account in connection with groundwater resources.
\end{abstract}

Key words: precipitation, specific discharge, water resources, the Kuyavian-Pomeranian Voivodship, Poland.

\section{Introduction}

The Kuyavian-Pomeranian Voivodship is located in the central part of Poland and covers an area of $17972 \mathrm{~km}^{2}$, which is $5.7 \%$ of the area of Poland (GUS, 2018). In terms of land use, the Kuyavian-Pomeranian Voivodship belongs to the agricultural regions. The area of agricultural land takes $65.3 \%$ of the voivodship, while forest areas constitute $24.5 \%$. The most favourable natural conditions for agricultural production are there in the districts of Inowrocław, Radziejów, Żnin, Aleksandrów as well as Torun, Chełmno and Grudziądz. An important factor facilitating agricultural economy in these areas is favourable, flat terrain features. The Kuyavian-Pomeranian region is also distinctive due to one of the lowest annual precipitation sums and summer half-year, i.e. from April to September, precipitation sums in Poland (Bąk \& Łabędzki, 2014; Bąk \& Kubiak-Wójcicka, 2017; Łabędzki \& Ostrowski, 2018; Kubiak-Wójcicka \& Bąk, 2018). In terms of surface water resources, the Kuyavian-Pomeranian region, and in particular its southern part, is the area with the largest water deficiency in Poland (Gutry-Korycka et al., 2014; Bartczak, Glazik, \& Tyszkowski, 2014). One of the methods to compensate for the negative water balance is to supplement atmospheric precipitation by irrigation and use of ground retention resources. Irrigation requires sustaining an adequate amount of water supplied to the crops. The use of ground retention resources is based on local water resources natural or appropriately increased by agrotechnical measures, as well as by properly operated drainage devices (Przybyła et al., 2008). Water deficiencies are particularly grievous during the growing season, which affects the volume of agricultural production (Żarski et al., 2013; Kuśmierek-Tomaszewska et al., 2018). In 2015, the Kuyavian-Pomeranian Voivodship took the second place in Poland in terms of the area of agricultural land used for the cropping of ground vegetables (245.33 $\mathrm{km}^{2}$ according to GUS data). The highest percentage of farms cropping vegetables are in the districts of Inowrocław, Radziejów and Włocławek (Rudnicki \& Kluba, 2014).

The paper characterizes the volume of precipitation and air temperature in the Kuyavian-Pomeranian Voivodship, as well as conducts the analysis of surface water resources. Particular attention has been paid to whether surface water resources are able to protect agricultural areas from the negative effects of drought and to mitigate the damage to agriculture caused by the lack or insufficient amount of precipitation. These activities are of great importance in the planning, preparation and undertaking the activities aimed at avoiding or reducing the negative effects of drought (Łabędzki \& Bąk, 2014).

The aim of this study is to present the spatial diversity of the specific discharge in the watercourses of the Kuyavian-Pomeranian Voivodship during the drought in 2015. The analysis was based on meteorological and hydrological data from the Institute of Meteorology and Water Management - National Research Institute (in Polish IMGW-PIB) and on own field research. The obtained results will allow to determine whether water intake from nearby rivers is possible for the purpose of irrigating agricultural areas during a period of small sums of precipitation in the vegetation season.

\section{Materials and Methods}

To characterise the meteorological conditions in the Kuyavian-Pomeranian Voivodship, daily sums of precipitation from 11 meteorological stations located within the administrative boundaries of the 
voivodship were used. For 5 of them, annual averages and maximum air temperatures are presented. The data on daily discharge of major rivers in 2015 was used to assess the water resources of the KuyavianPomeranian region. In total, the data for 9 rivers where regular hydrological observations are carried out was analysed. Both meteorological and hydrological data come from the Institute of Meteorology and Water Management - National Research Institute.

The hydrological observations of the IMGWPIB were supplemented by own field studies, which were carried out in September 2015. The choice of measurement dates resulted from the long-term period with low precipitation (June-August) and its potential impact on water resources in river basins. In total, hydrological observations and measurements were collected at 145 points in various watercourses located throughout the Kuyavian-Pomeranian Voivodship. The measurements included watercourses with small catchments, whose areas ranged from $30 \mathrm{~km}^{2}$ to $600 \mathrm{~km}^{2}$, and which are not covered by the standard monitoring system by the IMGW-PIB. Based on the results of discharge measurements, specific discharges were calculated. The specific discharge from a catchment area was calculated as the quotient of the average discharge and the catchment area, which made it possible to compare water resources of various rivers of the region. On the basis of the obtained values, a map of specific discharges during the hydrological drought was made.

\section{Results and Discussion}

The factor strongly influencing the size of the runoff and the river regime features are precipitation and air temperature. In 2015, the annual sums of precipitation in the Kuyavian-Pomeranian Voivodship were diversified in both spatial and temporal terms. The lowest precipitation during the year was recorded in Płock (319 mm), while the highest - in Nowy Jasiniec (436.7 mm) (Table 1). In Torun, the annual precipitation was $379.4 \mathrm{~mm}$, which constituted only $70 \%$ of the long-term standard for 1981-2010 (GUS, 2018).

During the year, the lowest precipitation occurred in February in the majority of the area of the Kuyavian-Pomeranian Voivodship, and in its southern part - in August (Figure 1). Monthly precipitation on most meteorological stations did not exceed 20 $\mathrm{mm}$, and in case of some of them didn't even reach $10 \mathrm{~mm}$. In Torun, the precipitation total in August was $3.9 \mathrm{~mm}$. A lower value, i.e. $2.7 \mathrm{~mm}$, was only recorded in August 1984. That monthly precipitation accounted for only $1 \%$ of the annual sum in 2015, and compared to the long-term average it was less than $6 \%$ (Raport o stanie środowiska w województwie kujawsko-pomorskim w 2015 roku, 2016). At most meteorological stations, the highest precipitation was recorded in July. The exception was the highest monthly precipitation recorded in September at the Nowy Jasiniec meteorological station.

The year 2015 in the Kuyavian-Pomeranian Voivodship was much warmer than the multi-year average. The average annual air temperature at selected meteorological stations ranged from $9.3{ }^{\circ} \mathrm{C}$ in Chrząstowo to $9.9^{\circ} \mathrm{C}$ in Toruń. In relation to the longterm average from 1981 to 2010 , in Torun it was $1.4^{\circ} \mathrm{C}$ warmer. By far the warmest month in terms of average monthly air temperature at all meteorological stations

Table 1

Average annual air temperature and total precipitation on selected meteorological stations in 2015 (on the basis of data from the IMGW-PIB)

\begin{tabular}{|c|c|c|c|c|c|c|}
\hline $\begin{array}{l}\text { Meteorological } \\
\text { station }\end{array}$ & Longitude & Latitude & $\begin{array}{l}\text { Average air } \\
\text { temperature in }{ }^{\circ} \mathrm{C} \\
(\max / \mathrm{month})\end{array}$ & $\begin{array}{l}\text { Annual total } \\
\text { precipitation } \\
(\mathrm{mm})\end{array}$ & $\begin{array}{c}\text { Maximal } \\
\text { precipitation in } \\
\text { a year }\end{array}$ & $\begin{array}{c}\text { Minimal } \\
\text { precipitation }\end{array}$ \\
\hline $\begin{array}{c}\text { Bydgoszcz- } \\
\text { Szwederowo (A) }\end{array}$ & $17^{\circ} 59^{\prime} \mathrm{E}$ & $53^{\circ} 05^{\prime} \mathrm{N}$ & - & 320.2 & $65.5(\mathrm{VII})$ & 5.3 (II) \\
\hline Chrząstowo (B) & $17^{\circ} 35^{\prime} \mathrm{E}$ & $53^{\circ} 11^{\prime} \mathrm{N}$ & $9.3(35.9 / \mathrm{VIII})$ & 365.7 & 57.3 (VII) & 5.8 (II) \\
\hline Głodowo (C) & $19^{\circ} 14^{\prime} \mathrm{E}$ & $52^{\circ} 50^{\prime} \mathrm{N}$ & 9.4 (35.8/VIII) & 362.4 & 76.9 (VII) & 6.5 (VIII) \\
\hline Grudziądz (D) & $18^{\circ} 43^{\prime} \mathrm{E}$ & $53^{\circ} 26^{\prime} \mathrm{N}$ & - & 369.8 & 55.8 (VII) & 6.8 (II) \\
\hline $\begin{array}{c}\text { Janowiec } \\
\text { Wielkopolski (E) }\end{array}$ & $17^{\circ} 29^{\prime} \mathrm{E}$ & $52^{\circ} 46^{\prime} \mathrm{N}$ & - & 408.7 & 81.7 (VII) & 16.1 (II) \\
\hline Kołuda Wielka (F) & $18^{\circ} 09^{\prime} \mathrm{E}$ & $52^{\circ} 44^{\prime} \mathrm{N}$ & 9.7 (35.7/VIII) & 398.1 & 107.4 (VII) & 6.9 (VIII) \\
\hline Nowy Jasiniec $(G)$ & $18^{\circ} 02^{\prime} \mathrm{E}$ & $53^{\circ} 21^{\prime} \mathrm{N}$ & - & 436.7 & $62.1(\mathrm{IX})$ & 7.7 (II) \\
\hline Pakość $(\mathrm{H})$ & $18^{\circ} 05^{\prime} \mathrm{E}$ & $52^{\circ} 48^{\prime} \mathrm{N}$ & - & 348.0 & 84.5 (VII) & 9.8 (II) \\
\hline Płock (I) & $19^{\circ} 43^{\prime} \mathrm{E}$ & $52^{\circ} 35^{\prime} \mathrm{N}$ & $9.8(36.5 / \mathrm{VIII})$ & 319.0 & 58.6 (VII) & 3.0 (II) \\
\hline Śliwice $(\mathrm{J})$ & $18^{\circ} 11^{\prime} \mathrm{E}$ & $53^{\circ} 42^{\prime} \mathrm{N}$ & - & 396.6 & 62.9 (VII) & 2.1 (II) \\
\hline Torun $(\mathrm{K})$ & $18^{\circ} 35^{\prime} \mathrm{E}$ & $53^{\circ} 02^{\prime} \mathrm{N}$ & $9.9(36.2 / \mathrm{VII})$ & 379.4 & 98.5 (VII) & 3.9 (VIII) \\
\hline
\end{tabular}




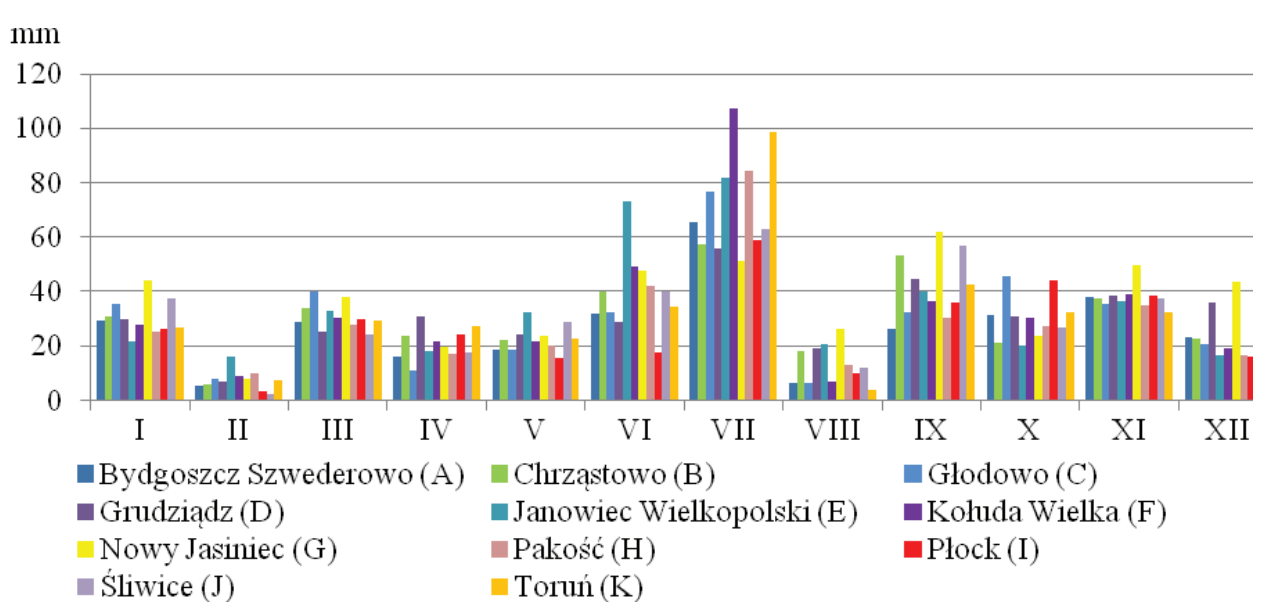

Figure 1. Average monthly precipitation in 2015 at selected meteorological stations (based on the data from the IMGW-PIB).

was August. The average monthly air temperature in August exceeded $20{ }^{\circ} \mathrm{C}$ (Figure 2). At all stations, except for Torun, this month also recorded absolute annual maximum temperatures, which ranged from $35.7{ }^{\circ} \mathrm{C}$ in Kołuda Wielka to $36.5{ }^{\circ} \mathrm{C}$ in Płock. In Toruń, the annual maximum of $36.2{ }^{\circ} \mathrm{C}$ was recorded in July, while in August the maximum temperature was slightly lower and amounted to $36.1^{\circ} \mathrm{C}$.

It should therefore be stated that in 2015 the prevailing area of the province was very dry or dry in relation to the long-term period both in terms of precipitation totals and air temperature.

Low precipitation totals in the first half of 2015 and increasing air temperature in subsequent months contributed to creation areas of soil drought in the Kuyavian-Pomeranian Voivodship. According to the reports prepared on the basis of the climatic water balance and posted on the website of the Agricultural Drought Monitoring System (www.susza.iung. pulawy.pl) run by the Institute of Soil Science and Plant Cultivation - State Research Institute in Puławy, soil drought began to arise as early as in the third decade of June.
The Kuyavian-Pomeranian Voivodship in comparison with other regions of Poland is characterized by low water abundance, as evidenced by the smallest average specific discharge (below $4 \mathrm{dm}^{3} \mathrm{~s}^{-1} \mathrm{~km}^{-2}$ ) (Gutry-Korycka et al., 2014). In the area of Kuyavia and some river basins, e.g. Zgłowiączka, the specific discharge was even lower and totalled below $2.5 \mathrm{dm}^{3} \mathrm{~s}^{-1} \mathrm{~km}^{-2}$ (Bartczak, Glazik, \& Tyszkowski, 2014). The main hydrographic axis of the region is the Vistula River, which in the Kuyavian-Pomeranian region is a transit river. The average specific discharge for the entire Vistula basin in the years 1951-2015 totalled $5.4 \mathrm{dm}^{3} \mathrm{~s}^{-1} \mathrm{~km}^{-2}$ (Kubiak-Wójcicka, 2019). In 2015, the average specific discharge of the Vistula River was lower than the average for the multi-year period and ranged $3.56 \mathrm{dm}^{3} \mathrm{~s}^{-1} \mathrm{~km}^{-2}$ in Torun. The highest specific discharge values were recorded in February $\left(4.64 \mathrm{dm}^{3} \mathrm{~s}^{-1} \mathrm{~km}^{-2}\right)$, while the lowest were recorded in September $\left(1.26 \mathrm{dm}^{3} \mathrm{~s}^{-1} \mathrm{~km}^{-2}\right)$ (Table 2).

The rivers Brda and Wda (northern part of the province) are characterized by the largest water abundance in the region. Their average specific

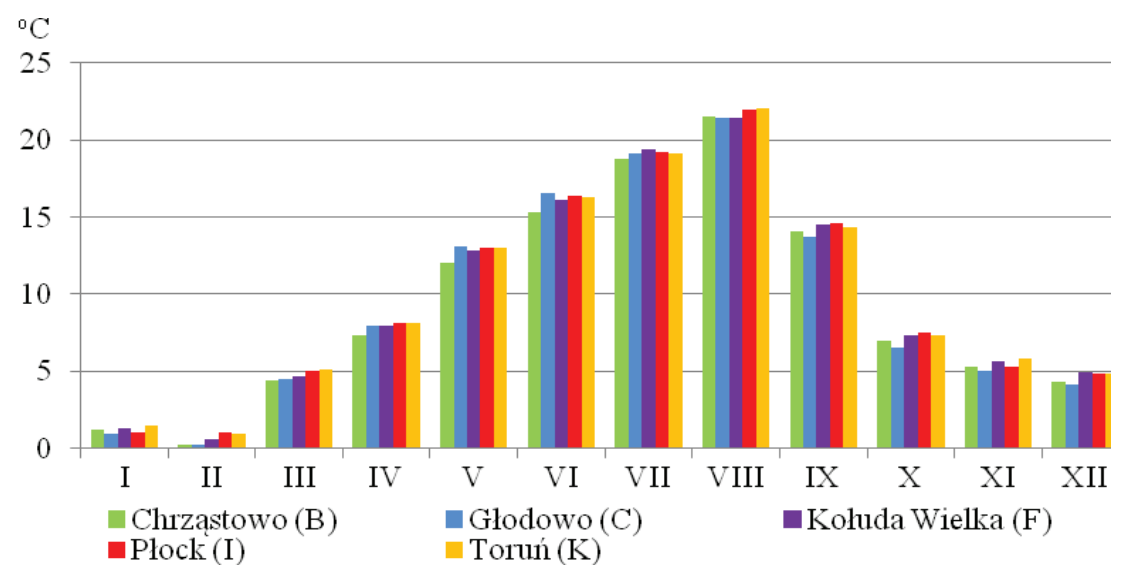

Figure 2. Average monthly air temperature in 2015 at selected meteorological stations. 
Table 2

Average, maximum and minimum specific discharge in 2015 at selected hydrological stations (own calculations on the base of the data from the IMGW-PIB)

\begin{tabular}{|c|c|c|c|c|c|c|}
\hline No. & River & $\begin{array}{c}\text { Hydrological } \\
\text { station }\end{array}$ & $\begin{array}{c}\text { Catchment area } \\
\left(\mathrm{km}^{2}\right)\end{array}$ & $\begin{array}{c}\text { Maximum } \\
\text { specific discharge } \\
\left(\mathrm{dm}^{3} \mathrm{~s}^{-1} \cdot \mathrm{km}^{-2}\right)\end{array}$ & $\begin{array}{c}\text { Average specific } \\
\text { discharge } \\
\left(\mathrm{dm}^{3} \mathrm{~s}^{-1} \mathrm{~km}^{-2}\right)\end{array}$ & $\begin{array}{c}\text { Minimum } \\
\text { specific discharge } \\
\left(\mathrm{dm}^{3} \cdot \mathrm{s}^{-1} \cdot \mathrm{km}^{-2}\right)\end{array}$ \\
\hline 1 & Vistula & Toruń & 180390.67 & 9.04 & 3.56 & 1.26 \\
\hline 2 & Wda & Krąplewice & 2025.83 & 6.27 & 4.02 & 2.75 \\
\hline 3 & Drwęca & Brodnica & 3539.83 & 5.54 & 3.02 & 1.29 \\
\hline 4 & Drwęca & Elgiszewo & 5019.48 & 5.56 & 2.62 & 1.14 \\
\hline 5 & Brda & Tuchola & 2477.16 & 10.17 & 5.90 & 3.46 \\
\hline 6 & Brda & Smukała & 4455.19 & 8.37 & 4.44 & 2.27 \\
\hline 7 & Osa & Rogóźno & 1135.11 & 2.45 & 1.36 & 0.36 \\
\hline 8 & Noteć & Pakość & 2356.20 & 1.95 & 1.26 & 0.59 \\
\hline 9 & Zgłowiączka & Włocławek-Ruda & 1491.82 & 1.40 & 0.53 & 0.12 \\
\hline 10 & Mień & Lipno & 230.65 & 3.21 & 1.24 & 0.56 \\
\hline 11 & Tążyna & Otłoczynek & 431.20 & 0.83 & 0.21 & 0.03 \\
\hline
\end{tabular}

discharges in 2015 were over $4 \mathrm{dm}^{3} \mathrm{~s}^{-1} \mathrm{~km}^{-2}$. The lowest average specific discharge in Poland occurred in the southern part of the Kuyavian-Pomeranian Voivodship. The smallest water abundance characterise the rivers Tążyna and Mień, for which the average annual specific discharge in 2015 amounted to $0.21 \mathrm{dm}^{3} \mathrm{~s}^{-1} \mathrm{~km}^{-2}$ and $0.53 \mathrm{dm}^{3} \mathrm{~s}^{-1} \mathrm{~km}^{-2}$, respectively. The seasonal distribution shows a clear differentiation of low specific discharges (Figure 3). The highest low specific discharges were recorded in winter and spring months, while the lowest - in the summer months, with extremely low specific discharges in August and September. The lowest monthly low specific discharges in August and September resulted from very low precipitation in August (below $20 \mathrm{~mm}$ ) and relatively high air temperatures (above $20{ }^{\circ} \mathrm{C}$ ).

Observations and hydrological measurements have shown the spatial range of the hydrological drought in 2015 and the regional variability of water resources (Figure 4). Areas with the lowest specific discharge $\left(<0.1 \mathrm{dm}^{3} \mathrm{~s}^{-1} \mathrm{~km}^{-2}\right)$ cover the upper parts of the Kuyavian river basins (Zgłowiączka, tributaries of the Noteć), of Chełmińskie Lake District (Fryba, Struga Toruńska, Górny Canal, Struga Wąbrzeska) and fragments of the Krajna Upland and Świecie Upland. In the case of small watercourses, which are fed with shallow circulation water, drying of riverbeds took place. The issue of lack of water in riverbeds also pertained to larger rivers flowing through the lakes. In the period of high air temperatures, evaporation from surface of water increased considerably. There was a significant decrease of the water level in the lakes. As a result of this phenomenon, the beds of some rivers, e.g. Gardęga below Lake Nogat, Struga Toruńska below Lake Mlewieckie and Szumionka below Lake Gwiazda were dry. Extremely low discharge of $1.4 \mathrm{dm}^{3} \mathrm{~s}^{-1}$ occurred in Zgłowiączka below Lake Głuszyńskie. The process of disappearance of discharge and drying of river beds began in some rivers already in May (08/05/2015), e.g. in Struga Toruńska

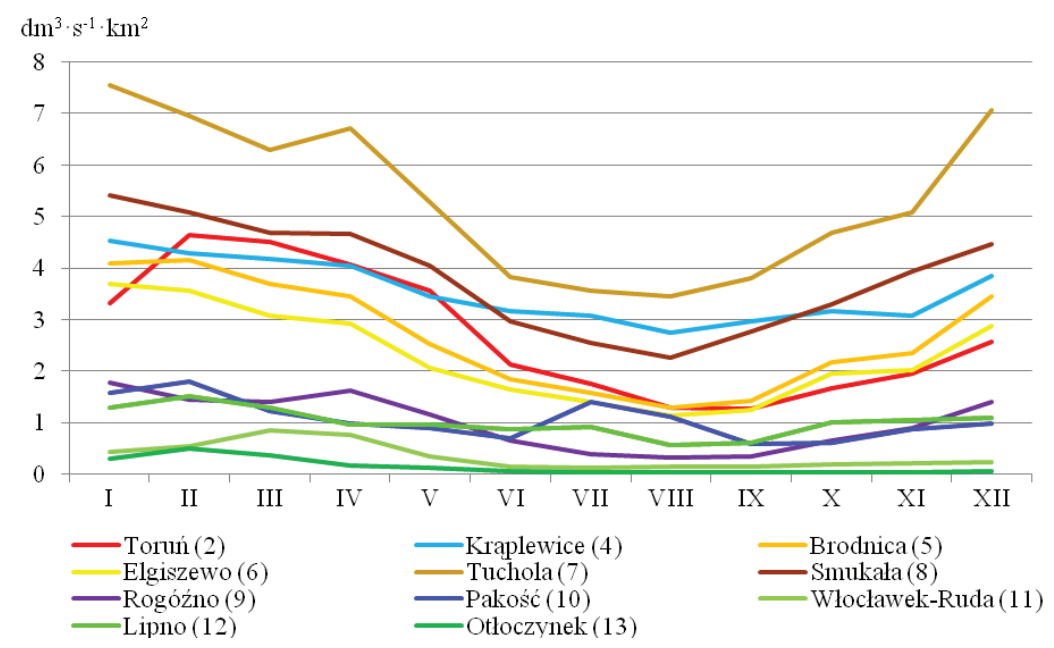

Figure 3. Lowest specific discharges in 2015 (on the base of the data from the IMGW-PIB). 


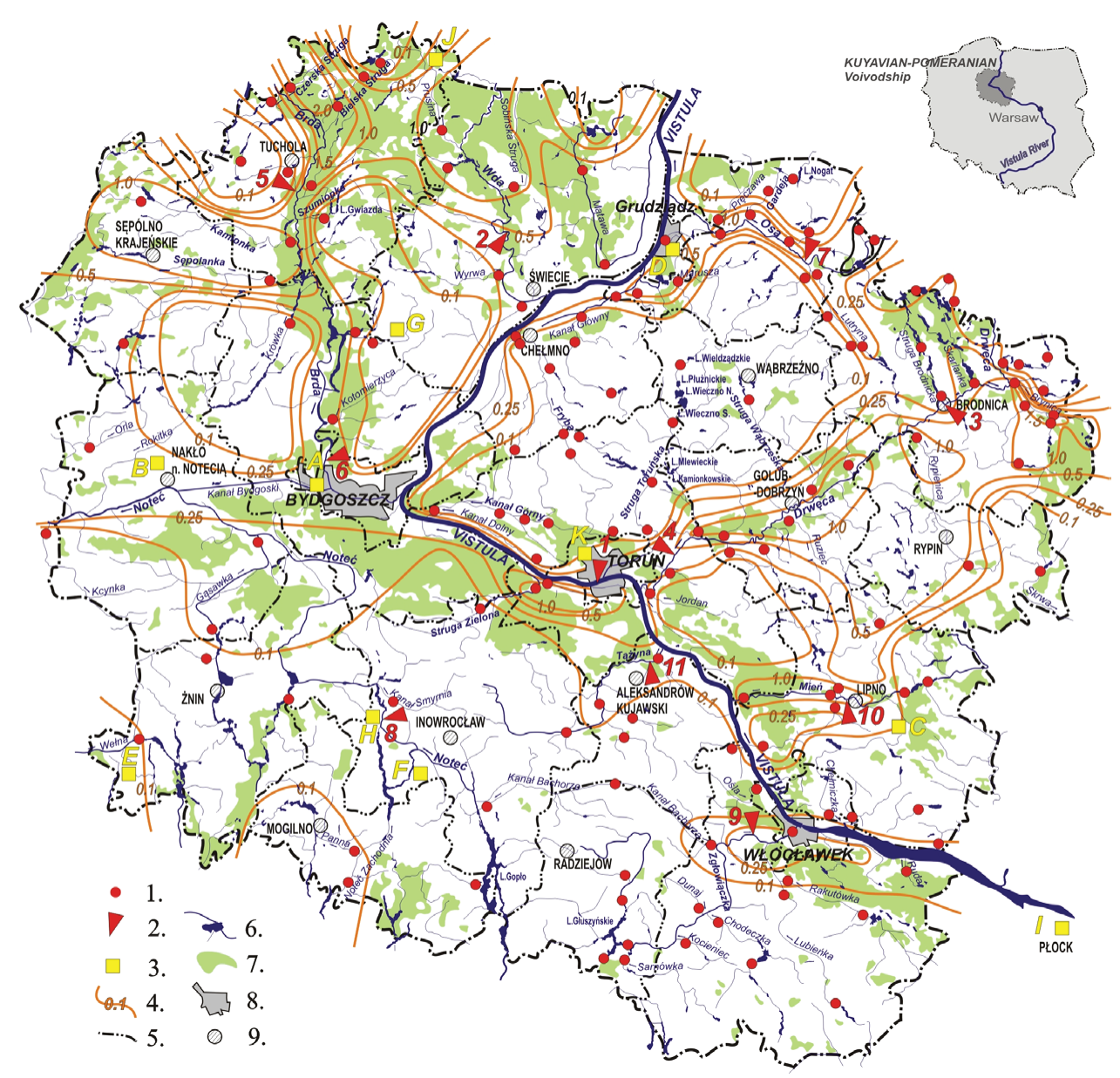

Figure 4. Map of the lowest low specific discharges $\left(\mathrm{dm}^{3} \mathrm{~s}^{-1} \mathrm{~km}^{-2}\right)$ during hydrological drought in September 2015 (Legend: 1. Points of hydrological observations and measurements in 2015; 2. Meteorological stations; 3. Hydrological stations; 4. Lines of identical specific discharge;

5. Border of conties; 6. Lakes and rivers; 7 Forests; 8. Urban area; 9. Cities).

below Lake Mlewieckie and lasted until mid-October (Sobota, 2016). In connection with the hydrological drought, the large lakes through which Struga Toruńska flows - Wieldządzkie, Płużnickie, Wieczno Północne and Wieczno Południowe - have become endorheic (Solarczyk, Napiórkowski \& Dembowska, 2017). During the hydrological drought the runoff in rivers is formed by an underground inflow. The ability to supply underground water to a deeper waterbearing system of rivers depends, among others on the range of the aquifer and the extent to which the valleys and riverbeds have cut into the surrounding land. During the drought, the largest specific discharges were recorded in the estuary sections of rivers flowing from the upland areas, as well as fragments of the sand region of the north-western part of the province (Bory Tucholskie). Runoff over $1.5 \mathrm{dm}^{3} \mathrm{~s}^{-1} \mathrm{~km}^{-2}$ occurred in the lower parts of catchments of the Brynica (eastern part of the province), Mień, Struga Zielona, Osa, and in catchments of the Sepolenka and Kamionka. In the catchments of Czerska Struga, Bielska Struga and left bank Brda tributaries, the specific discharge was the highest in the province and exceeded the value of $2.0 \mathrm{dm}^{3} \mathrm{~s}^{-1} \mathrm{~km}^{-2}$.

The spatial distribution of specific discharges determined during the hydrological drought in 2015 is to a large extent similar to the distribution of the lines determining the lowest from low specific discharges for the period 1951-1970 (Stachy, 1979). The highest specific discharges occur in the north-western part of the voivodship, in the upper part of the Brda basin. The deep deficit of water resources covers the area of the upper part of the Noteć basin and the Zgłowiączka basin. In the majority of the Kuyavian-Pomeranian Voivodship, specific discharges in 2015 were lower than specific discharges determined for the period 1951-1970. A particularly unfavourable phenomenon aggravating the deficiency of water resources occurred in 2015 in the southern and south-western part of the province (Kuyavia). The phenomenon of soil drought and hydrological drought, covering areas with very favourable features for agricultural production, affects the yield of plants, especially root crops and vegetables harvested in the autumn. 


\section{Crop yields, root crops and vegetables $\left(\mathrm{dt} \mathrm{ha}^{-1}\right)$ in 2015 over the period 2010-2017 (own calculations} according to data from the GUS)

\begin{tabular}{|c|c|c|c|}
\hline Type of crop & $\begin{array}{c}\text { Average crop in } \\
2010-2017\end{array}$ & Crop in 2015 & $\begin{array}{c}\text { \% of 2015 crops related to the } \\
\text { period 2010-2017 }\end{array}$ \\
\hline Total cereals & 41.9 & 39.6 & 94.5 \\
\hline Corn for grain & 63.6 & 47.4 & 74.6 \\
\hline Potatoes & 257 & 250 & 97.3 \\
\hline Sugar beets & 585 & 472 & 80.6 \\
\hline Ground carrots & 381 & 347 & 91.1 \\
\hline Ground beetroot & 316 & 273 & 86.3 \\
\hline Ground onion & 247 & 241 & 97.5 \\
\hline Ground cabbage & 415 & 365 & 87.9 \\
\hline Ground cauliflower & 180 & 157 & 87.3 \\
\hline Ground cucumbers & 145 & 130 & 89.7 \\
\hline Tomatoes & 335 & 326 & 97.2 \\
\hline Other ground vegetables* & 135 & 126 & 93.1 \\
\hline Edible leguminous & 26.8 & 25.2 & 94.0 \\
\hline
\end{tabular}

* parsley, leeks, celery, radishes, lettuce and others.

The year 2015 belonged to dry years in the majority of the whole vegetation period throughout Poland (Kuchar et al., 2017). Problems with drought in 2015 in many regions of Poland appeared already in the spring. Significant shortages of precipitation were observed in winter and early spring (Labędzki \& Bąk, 2015). In 2015, when there were unfavorable conditions for plant growth, the yields of all types of crops decreased (Table 3). The yields of sugar beet and certain types of vegetables were particularly low. Higher losses in sugar beet yields are also caused by the lack of possibility of sprinkling irrigation the fields due to the large acreage these plants occupy. In the case of vegetables, water shortages in the ground could be replenished in some part of the area with sprinklers. Such treatments could have contributed to stopping the decline in total yields in the KuyavianPomeranian Voivodship. Irrigation of plants in Poland is interventional, supplementing periodic water shortages (Żarski et al., 2013). The use of irrigation will increase, which results from the necessity to ensure the stability of plant production and to meet the increasingly high quality requirements (Stachowski \& Markiewicz, 2011).

\section{Conclusions}

1. long-term persistence of meteorological drought in 2015 contributed to the reduction of water resources in the Kuyavian-Pomeranian Voivodship, which resulted in extremely low specific discharges. A significant reduction of water resources occurred first of all in the central parts of the plains and moraine plateaus, in intensively exploited agricultural areas and having the most favourable conditions for agriculture.

2. the highest values of specific discharge were recorded in the northern part of the KuyavianPomeranian Voivodship (the upper Brda River basin) and in the edge zones of the uplands and river valleys of the main Vistula tributaries.

3. the lowest specific discharges were recorded in the southern areas of the Kuyavian-Pomeranian Voivodship, intensively used for agriculture, in which the areas designated for the cultivation of ground vegetables are among the largest in Poland.

4. in the case of droughts occurring in summer periods, yields of root crops, in particular sugar beet and certain vegetables (cauliflower, cabbage, beetroot), have decreased. Obtaining crops at a satisfactory level during long periods with no or little precipitation is associated with the need to apply irrigation. As a consequence of this type of treatment, there is an additional depletion of water resources within the catchment, further decreasing the low flows in rivers, and even their total disappearance.

5. in the period of meteorological droughts, as it was the case in 2015, in a large part of the area there are limited possibilities of surface water intake for irrigation purposes. The use of surface water resources as a potential source of irrigation water for crops can only be taken into account in connection with groundwater resources.

\section{References}

1. Bartczak, A., Glazik, R., \& Tyszkowski, S. (2014). Czasowe i przestrzenne zróżnicowanie odpływu jednostkowego w zlewni rzeki Zgłowiączki (wschodnia cześć Kujaw) (Times and spaces diversity of the 
discharge in the Zgłowiączka river basin (Eastern part of Kujawy). Nauka-Przyroda-Technologie, 8, 3 \#28 (in Polish)

2. Bąk, B., \& Łabędzki, L. (2014). Prediction of precipitation deficit and excess in Bydgoszcz Region in view of predicted climate change. Journal of Water and Land Development, 23(X-XII), 11-19. DOI: 10.1515/ jwld-2014-0025.

3. Bąk, B., \& Kubiak-Wójcicka, K. (2017). Impact of meteorological drought on hydrological drought in Torun (central Poland) in the period of 1971-2015. Journal of Water and Land Development, 32(I-III), 3-12. DOI: 10.1515/jwld-2017-0001.

4. Główny Urząd Statystyczny (GUS) (2018). Central Statistical Office. Statistical yearbook of the Republic of Poland, Retrieved February 10, 2019, from https://stat.gov.p1/.

5. Gutry-Korycka, M., Sadurski, A., Kundzewicz, Z.W., Pociask-Karteczka, J., \& Skrzypczyk, L. (2014). Zasoby wodne a ich wykorzystanie (Water resources and their use). Nauka, 1, 77-98. (in Polish)

6. Kubiak-Wójcicka, K., \& Bąk, B. (2018). Monitoring of meteorological and hydrological droughts in the Vistula basin (Poland). Environmental Monitoring and Assessment, 190, 11, 1-16. DOI: 10.1007/s10661018-7058-8.

7. Kubiak-Wójcicka, K. (2019). Long-term variability of runoff of Vistula River in 1951-2015. Air and water - Components of the Environment, Conference Proceedings, Cluj-Napoca, Romania, 109-120. DOI: 10.24193/AWC2019 11.

8. Kuchar, L., Iwański, S., Diakowska, E., \& Gąsiorek, E. (2017). Ocena suszy meteorologicznej w 2015 roku w północnej części północnej Polski z wykorzystaniem wskaźnika hydrotermicznego (HTC) w kontekście zmian klimatycznych (Assessment of meteorological drought in 2015 for north central part of Poland using hydrothermal coefficient (HTC) in the context of climate change). Infrastruktura i Ekologia Terenów Wiejskich, I/2, 257-273. DOI: 10.14597/infraeco.2017.1.2.019. (in Polish)

9. Kuśmierek-Tomaszewska, R., Dudek, S., Żarski, J., \& Januszewska-Klapa, K. (2018). Temporal variability of drought in field crops in the region of Kujawsko-Pomorskie, Poland. Agricultures Sciences Research For Rural Development, 2, 62-68. DOI: 10.22616/rrd.24.2018.052.

10. Łabędzki, L., \& Bąk, B. (2014). Meteorological and agricultural drought indices used in drought monitoring in Poland: a review. Meteorology, Hydrology and Water Management, 2 (2), 3-13.

11. Łabędzki, L., \& Bąk, B. (2015). Susza w Polsce w 2015 roku i ocena skutków na trwałych użytkach zielonych (Drought in Poland in 2015 and an assessment of impacts in permament grassland). Wiadomości Melioracyjne i Łakkarskie, 3, 102-106. (in Polish)

12. Łabędzki, L., \& Ostrowski, J. (2018). Precipitation preventing a deficit of readily available soil water in arable soils in Poland. Atmosphere, 9, 121, DOI: 10.3390/atmos9040121.

13. Przybyła, Cz., Mrozik, K., Bykowski, J., Kozaczyk, P., \& Sielska, I. (2008). Niedobory wody i potrzeby nawodnień w zlewni Kościańskiego Kanału Obry (Water deficiency and irrigation needs in the drainage basin of the Kościan Obra Canal). Zeszyty Problemowe Postęów Nauk Rolniczych, 532, 237-245. (in Polish)

14. Rudnicki, R., \& Kluba, M. (2014). Użytkowanie ziemi i produkcja rolnictwa w województwie kujawskopomorskim w latach 2002-2010. Studium statystyczno-przestrzenne (Land use and production of agriculture in the Kuyavian-Pomeranian Voivodship in the years 2002-2010. Statistical and spatial study). Wyd. Nauk. UMK, pp. 291. (in Polish)

15. Sobota, I. (2016). Odpływ wody ze zlewni reprezentatywnej Strugi Toruńskiej w 2015 roku, (Water outflow from the representative catchment of the Struga Toruńska in 2015). (in:) Raport z realizacji programu badawczo-pomiarowego Zintegrowanego Monitoringu Środowiska Przyrodniczego w Stacji Bazowej Koniczynka w 2015 roku, (Ed.), M. Kejna, mscr. (in Polish)

16. Solarczyk, A., Napiórkowski, P., \& Dembowska, E. (2017). Stan geoekosystemów jeziornych dorzecza Strugi Toruńskiej w zmieniających się warunkach klimatyczno-hydrologicznych (The state of lake geoecosystems of the Struga Toruńska catchment in changing climatic and hydrological conditions). (in:) Zintegrowany Monitoring Środowiska Przyrodniczego. Funkcjonowanie środowiska przyrodniczego Polski w warunkach globalnych zmian klimatycznych. (Eds.). M. Kejna \& J. Uscka-Kowalkowska, Wyd. Nauk. UMK. Toruń (in Polish)

17. Stachy, J. (1979). Reżym hydrologiczny rzek Polski (Hydrological regime of the Polish rivers). (in:) Odpływ rzek Polski w latach 1951-1970. Materiały Badawcze IMGW, Ser. Spec., 6 (in Polish)

18. Stachowski, P., \& Markiewicz, J. (2011). Potrzeba nawodnień w centralnej Polsce na przykładzie powiatu kutnowskiego (The need of irrigation in central Poland on the example of the Kutno county). Rocznik Ochrona Środowiska, 13, 1453-1472. (in Polish) 
19. Żarski, J., Dudek, S., Kuśmierek-Tomaszewska, R., \& Januszewska-Klapa, K. (2013). Potrzeby i efekty nawadniania kukurydzy uprawianej na ziarno w regionie kujawsko-pomorskim (Needs and effects of irrigation in corn cultivated for grain in the Kujawsko-Pomorskie region). Infrastruktura $i$ Ekologia Terenów Wiejskich, 3/IV, 77-90. (in Polish) 